\title{
Use of a lignocellulosic residue as solid fuel: The effect of ash content in the energy potential
}

\author{
Ana Larissa Santiago Hansted ${ }^{\mathrm{a}}$, Thiago Aguiar Cacuro ${ }^{\mathrm{b}}$, Gabriela Tami Nakashima ${ }^{\mathrm{b}}$, \\ Vladimir Eliodoro Costa ${ }^{\mathrm{a}}$, Hiroyuki Yamamoto ${ }^{\mathrm{c}}$, Fábio Minoru Yamaji ${ }^{\mathrm{b}, *}$ \\ ${ }^{a}$ Department of Physics and Biophysics, State University of São Paulo, 18618-689, Brazil \\ b Department of Environmental Sciences, Federal University of São Carlos, 18052-780, Brazil \\ ${ }^{c}$ Department of Biomaterials Sciences, Nagoya University, 464-8601, Japan
}

\section{A R T I C L E I N F O}

\section{Keywords:}

Biomass

Bioenergy

Bark

Eucalyptus

High heating value

\begin{abstract}
A B S T R A C T
Bark is a residue that can be used as fuel by the industry. One of the problems of its use is the impurity that it may contain. This study aimed to characterize physically and thermo-chemically the eucalyptus bark used as a fuel in a wood panel industry, relating the high heating value (HHV) with the ash content. Six treatments were provided according to particle size and washing process of the bark: T1 ( $850 \mu \mathrm{m}$ to $425 \mu \mathrm{m} / \mathrm{unwashed})$, T2 (retained on $250 \mu \mathrm{m} /$ unwashed), T3 ( $<150 \mu \mathrm{m} /$ unwashed), T4 (850 $\mu \mathrm{m}$ to $425 \mu \mathrm{m} /$ washed), T5 (retained on $250 \mu \mathrm{m} /$ washed), T6 $(<150 \mu \mathrm{m} /$ washed). The material was assessed regarding moisture content. The treatments were subjected to HHV and proximate analysis. The ashes were analyzed under SEM-EDS to identify the components/impurities. The data obtained in this study were statistically analyzed using the software R. The material presented moisture content of $70 \%$ on a dry basis, which is considered high for use in bioenergy. It was identified the presence of silica and calcium in the ash, which indicates the presence of soil in the material. The process of washing the bark was efficient for the reduction in ash content only in particle size $<150 \mu \mathrm{m}$. The separation of the bark in particle size was a better technique to reduce the impurities. The proximate analysis showed a significant difference among treatments. The ash content presented values from $2.63 \%$ (T1) to $13.86 \%$ (T3). The HHV was $18828 \mathrm{~J} \mathrm{~g}^{-1}$ (T1) and $15757 \mathrm{~J} \mathrm{~g}^{-1}$ (T3). The separation in particle size reduced $81.02 \%$ in the ash content, which represented an increase of $21.05 \%$ in the HHV. This result showed the effect of the ash content in the energy potential.
\end{abstract}

\section{Introduction}

Power generation is a topic that over the years has gained more importance due to its influence on economic stability and also political and environmental issues. Renewable resources are alternative energy sources, which may have advantages compared to fossil fuels, such as availability, easy workability, and lower cost. The renewable energy source is already seen as sustainable, and has presented a growing usage fee (Eia, 2015; Nematollahi et al., 2016).

Different sectors can provide biomass, such as lignocellulosic materials, agro-food and also waste from any organic source (Akbi et al., 2017). There is a high availability of biomass in Brazil. This biomass is mainly derived from plantations with energy purposes or from plantations' residue. The area of planted forests is of approximately 7.6 million hectares, of which almost $70 \%$ are eucalyptus forests (Ibá, 2015).

Biomass provided from vegetable resources represents a very important storage of energy. In order to use this energy, it is necessary to perform an appropriate process, such as burning/combustion (Madanavake et al., 2017). The combustion of the biomass is already a very common practice in several industrial sectors. It is usually inserted into a boiler, in which is provided heating and drying, followed by pyrolysis, combustion and post-combustion. This entire process can release hot air, and heat water and oil (Moraes, 2013).

This process may also offer some drawbacks. Biomasses frequently are presented in uneven characteristics, and can be classified energetically according to the moisture content (MC), impurities compounds (ash content), and high heating value (HHV) (Furtado et al., 2012). Modifications in any of these parameters will have an effect on the energy generation. It is recommended that energetic materials have a MC smaller than $10 \%$ (in dry basis) and up to $2 \%$ of ash content (Enplus, 2015).

The ash content is an inorganic residue that represents the percentage of the material that is not part of the burning process and its increase represents a reduction in the HHV. This component may also

\footnotetext{
* Corresponding author

E-mail address: fmyamaji@ufscar.br (F.M. Yamaji).
} 
result in damage to the burning equipment by corrosive processes or by the material deposition on the structure which may reduce the thermal capacity (Garcia et al., 2014). Consequently, there is a concern about the reduction of ash content to prevent maintenance of equipment or to optimize the heat generation.

The ash content of a biomass may vary with the availability of minerals from the soil where it is developed. The minerals are absorbed by the plant and can be found in all organs and tissues. When the ash content is over the expected value, there is the possibility of the material having some type of external contamination (Fredo et al., 1999; Hansted et al., 2016).

The ashes are heterogeneous regarding their composition, varying according to the source of biomass and the burning process (Vassilev and Vassileva, 2007). The ashes present main components in their structure, such as silicates, cenospheres, and carbonaceous particles. Silicates are particles with spherical shape, composed by silica dioxide (SiO2); cenospheres are spherical particles composed by a mixture of metal oxides; and carbonaceous are particles with irregular shape, mainly the remaining parts of the incomplete burning, which may be present in the material when it is burned in commercial scales (Hwang et al., 2002; Cordeiro et al., 2008; Ahmaruzzaman, 2010).

The physicochemical characterization allows a better understanding of the material, enabling the implementation of treatments for the optimization of biomass use. The main purpose of this study was the physicochemical characterization of eucalyptus bark used as fuel in a wood panel industry. The specific objectives were to identify methods to reduce the biomass impurities.

\section{Materials and methods}

\subsection{Material}

The biomass was collected in a wood panel company in the city of Itapetininga/SP-Brazil $\left(23^{\circ} 35^{\prime} 40^{\prime \prime} \mathrm{S}\right.$; $\left.48^{\circ} 3^{\prime} 14^{\prime \prime} \mathrm{W}\right)$. The material is originated from plantations of hybrid eucalyptus (Eucalyptus urophylla $\mathrm{x}$ Eucalyptus grandis) with seven years old. The material used was the bark, obtained after the debarking of the logs. This process was held at the company's yard.

\subsection{Preparation of the bark}

The bark was fragmented into small pieces and it was milled in a crushing machine. Before the process of milling, it was provided the treatments that will be detailed on item 2.4.

The original moisture content of the material was calculated according to ASTM E871-13 standard. The moisture content was calculated in dry basis, using the Eq. (1):

$M C=\frac{(w w-d w)^{*} 100}{d w}$

The variables shown in the formula represent: ' $M C$ ': moisture content in percentage; ' $w w$ ': wet weight in g; and ' $d w$ ': the dry weight in g.

In order to obtain the material dried, it was kept in the oven, at a temperature of $100^{\circ} \mathrm{C}$ until it presented constant weight.

\subsection{Treatments}

In the laboratory, the material was subjected to three different particle sizes separation (between 850 and $425 \mu \mathrm{m}$ sieve, retained on the $250 \mu \mathrm{m}$ sieve and smaller than $150 \mu \mathrm{m}$ sieve) and two processes regarding washing:

- washed (W) in running water for $10 \mathrm{~min}$, with a total volume of $2 \mathrm{~L}$; - unwashed (UW), the material was kept with the original characteristics.
Table 1

Treatments established regarding particle sizes and the process of washing the material.

\begin{tabular}{lll}
\hline Process & Treatments & Particle sizes $(\mu \mathrm{m})$ \\
\hline \multirow{2}{*}{ UW } & T1 & $850-425$ \\
& T2 & 250 \\
T3 & T4 & $>150$ \\
W & T5 & $850-425$ \\
& T6 & 250 \\
& & $>150$ \\
\hline
\end{tabular}

Resulting in six treatments according to Table 1:

\subsection{Particle size analysis}

The biomass was placed in a stack of sieves arranged from the largest to the smallest opening. The sieves sizes selected were: $850 \mu \mathrm{m}$, $425 \mu \mathrm{m}, 250 \mu \mathrm{m}, 150 \mu \mathrm{m}$, and $<150 \mu \mathrm{m}$, according to the standard ASTM D293-93 (2010). The set of sieves was placed on the Ro-Tap sieve shaker. The duration of sieving was $3 \mathrm{~min}$ and after sieving, the mass retained on each sieve was weighed.

\subsection{Proximate analysis}

Prior to these analyses, the biomasses (all treatments) were dried in an oven at $100{ }^{\circ} \mathrm{C}$. The determination of the ash content was held according to the standard ASTM D1102-84 (2007), and the volatile content, according to ASTM E872-82 (2013); both tests done in triplicates. Both standards were adapted, since all the material was used for the calculation. The fixed carbon content was calculated according to the Eq. (2):

$F C C=100-(A C+V C)$

The variables shown in the equation represent: $F C C=$ fixed carbon content (\%); $A C=$ ashes content (\%); and $V C=$ volatile content (\%).

\subsection{High heating value}

The high heating value of all treatments preformed was obtained in the calorimeter IKA C200 based on the standard ASTM D5865-13. For each treatment, three repetitions were carried out.

\subsection{Morphological characterization}

Morphological characterization of the ash was performed by scanning electron microscopy (SEM). The tests were performed at the Electron Microscopy Laboratory of the National Nanotechnology Laboratory using the microscope Inspect F50, by FEI.

In order to identify the components that were present in the SEM analysis, in other words, which mineral material constitutes the ashes, it was performed peripheral energy dispersive spectroscopy (EDS) analysis.

\subsection{Statistical analyses}

The effects of experimental treatments were analyzed using software $\mathrm{R}$ version 2.11.1,by analysis of variance (ANOVA) and Tukey's multiple range tests ( $5 \%$ of probability).

\section{Results and discussion}

The material was obtained in the same conditions in which it is used by the company, without any processing or cleaning. The initial moisture content was approximately $70 \%$ (dry basis). This high level may be explained by the storage in silos, without drying, keeping the moisture in the material. The high moisture content is a negative factor 
Table 2

Mean values and standard deviation of the proximate analysis of bark in the established treatments.

\begin{tabular}{lllll}
\hline & & Ashes (\%) & Volatile (\%) & Fixed Carbon (\%) \\
\hline UW & T1 & $2,63 \mathrm{c}( \pm 0.28)$ & $80,23 \mathrm{a}( \pm 0.26)$ & $17,12 \mathrm{a}( \pm 0.34)$ \\
& T2 & $5,23 \mathrm{~b}( \pm 0.36)$ & $76,89 \mathrm{~b}( \pm 0.62)$ & $17,86 \mathrm{a}( \pm 0.40)$ \\
& T3 & $13,86 \mathrm{a}( \pm 0.26)$ & $68,15 \mathrm{c}( \pm 0.20)$ & $17,98 \mathrm{a}( \pm 0.38)$ \\
$\mathrm{H}$ & T4 & $2,78 \mathrm{c}( \pm 0.12)$ & $79,58 \mathrm{a}( \pm 0.27)$ & $17,62 \mathrm{~b}( \pm 0.33)$ \\
& T5 & $3,12 \mathrm{~b}( \pm 0.15)$ & $79,73 \mathrm{a}( \pm 0.30)$ & $17,13 \mathrm{~b}( \pm 0.23)$ \\
& T6 & $5,15 \mathrm{a}( \pm 0.12)$ & $76,16 \mathrm{~b}( \pm 0.06)$ & $18,45 \mathrm{a}( \pm 0.30)$
\end{tabular}

for use in heat generation, since there is a loss of energy potential to the withdrawal of the excess water. It is recommended moisture content up to $10 \%$ for energy purposes (Enplus, 2015).

The eucalyptus bark, which is used as fuel by the company, goes through the stripper, which reduces the pieces dimensions. At the time of collection, the greatest percentage (55\%) of the material got retained on the sieve with opening of 2 " $(50 \mathrm{~mm})$. After the material passed through the mill, it showed smaller particles, with higher percentage (45\%) retained on the sieve with opening of $425 \mu \mathrm{m}$.

The results of proximate analysis for all treatments: unwashed (UW - T1, T2, T3) and washed (W - T4, T5, T6) are presented in Table 2, ANOVA and Tukey's test were applied. It was possible to notice that the values obtained for ash content in this study are above what was expected when comparing to other researches regarding eucalyptus bark. For instance, Chen et al. (2015) and Yu et al. (2016) presented values for ash content lower than $4 \%$. This difference can occur due to the eucalyptus harvesting process of the company, which may aggregate dirt to the bark.

In Table 2 it is possible to notice significant differences in the UW (unwashed) and W (washed) treatments. For both parameters, UW and $\mathrm{W}$, the highest percentage of ash is concentrated in the smaller particle sizes (T3 and T6).

To verify the differences in ash content, it was calculated the ANOVA between washed (W) and unwashed (UW) treatments (with the same particle size extracts). The results showed no significant difference between $\mathrm{T} 1$ and $\mathrm{T} 4$, that is, the washing does not influence the determination of the ash content in particles of $850-425 \mu \mathrm{m}$. The same pattern was observed for particles of $250 \mu \mathrm{m}$, and there was no significant difference between $\mathrm{T} 2$ and $\mathrm{T} 5$ treatments. For thinner material, $>150 \mu \mathrm{m}$ (T3 and T6), the washing resulted in a significant decrease in ash content. The material that showed no significant difference for washing process $(850-250 \mu \mathrm{m})$ represents $67 \%$ of the total sample. It means, washing the material was not an efficient method to reduce the impurities. This process reduced the ash content only in thinner particles. The particle size separation can be an efficient and suitable method for reduction in ash content, since it enables the process of separating the smaller particle sizes, which retains the major part of mineral contents (Acquah et al., 2016; Nakashima et al., 2017).

High levels of ash (minerals) represent a decrease in energy potential. The minerals do not participate in the combustion process and thus it is inversely proportional to the heat generation, Fig. 1 (Brand, 2010; Protásio et al., 2011; Montes et al., 2011). All minerals represent a loss in the heating potential, at the end of the combustion, the ashes remain (Boumanchar et al., 2017). Also, the presence of a great amount of ashes can result in loss of efficiency of the boiler; by turning the structure thicker, it can reduce the useful life of the equipment, since it generates corrosives processes, and increases the maintenance due to the crusting in the structure where the ashes are accumulated (Brand, 2010; Protásio et al., 2011; Montes et al., 2011; Sabatti et al., 2014).

The low ash content is one of the characteristics of eucalyptus, which makes it feasible for use in energy, presenting values below $1 \%$ (Gominho et al., 2012). The values obtained in this study for ash content were from $2 \%$ (T1) to $13.86 \%$ (T3). These high amounts of ash are explained by the external contamination of the material. With the particle size separation, and the process of washing the material, it was possible to identify the presence of impurities in the biomass. According to Pereira et al. (2000), it is predicted that there is greater susceptibility to impurities attached to the bark by dirt or any environment pollution.

The fixed carbon content is directly related to the quality of the biofuel. The amount of fixed carbon present in the biomass can define the potential for power generation. When in high amounts, from 15 to 25\% (Vanloo and Koppejan, 2002), it increases the efficiency due to the slow burning in the solid phase (Brito and Barrichelo, 1978; Erol et al., 2010; Todaro et al., 2015). The fixed carbon and volatile content are inversely related regarding energy, since the volatile fraction represents the part of the material that burns quickly in gaseous form, resulting in less burning time (Brito and Barrichelo, 1978).

The material presented the expected pattern, decreasing the high heating value (HHV) as the ashes content increased (Fig. 1):

Many studies have pointed the ash as a component that can help the prediction of the HHV (Cordero et al., 2001 and Shen et al., 2010). The HHV was harmed by the ash content as expected. Treatment T3 presented the highest ash content $(13,86 \%)$ and the lowest HHV (15 $757 \mathrm{~J} \mathrm{~g}^{-1}$ ). Arteaga-Pérez et al. (2015) also studied eucalyptus bark, and the highest result for HHV was $13340 \mathrm{~J} \mathrm{~g}^{-1}$. The HHV of bark may vary due to its impurities, since the heat potential of bark is the same of the stem (Telmo and Lousada, 2011).

In the mapping of the elements present in the samples (Fig. 2), it is possible to see the micrographs of the main particles found in the ash samples, generated upon burning the bark.

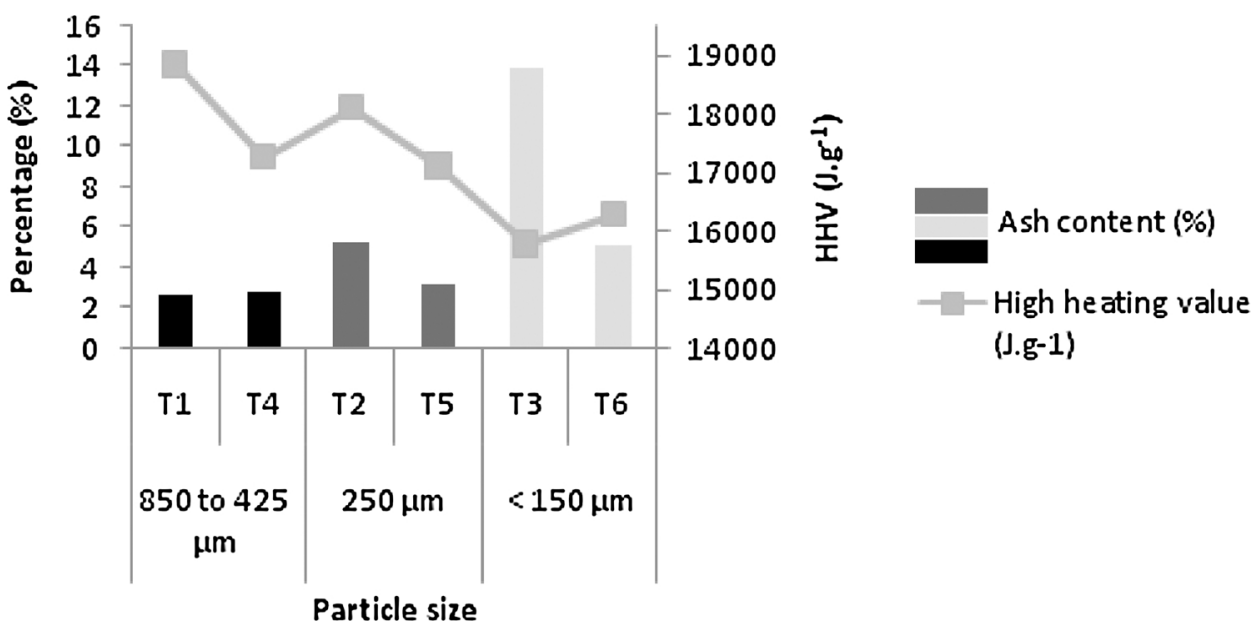

Fig. 1. Ash content of the six treatments and high heating value variation. 


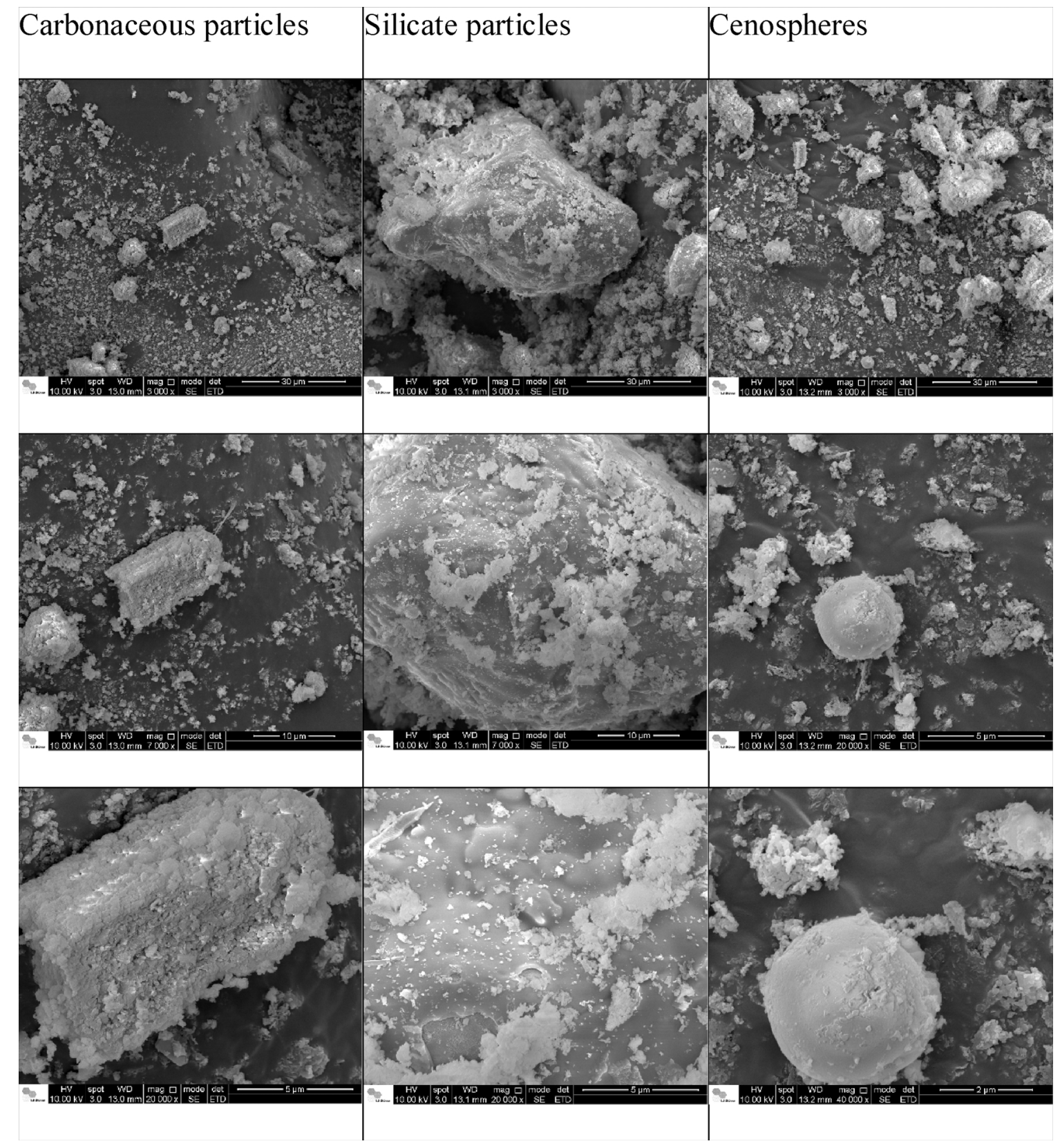

Fig. 2. Micrographs increasing the magnification of calcium particles in the first column, of silicates in the second, and of cenospheres in the third.

In the first column, it is possible to observe the particles with regular shape and many pores on their surface (identified as calcium by EDS Fig. 3a). This particle was presented in a high proportion in the samples.

In the second column, it is possible to observe the particles with angular walls and smooth surface, known in the literature as silicates (Ahmaruzzaman, 2010). They are often identified as components of the ashes (Blissett and Rowson, 2012).

In the third column, it is possible to visualize spherical particles known as cenospheres. These were the less abundant particles, presented only in part of the ash samples. According to the literature, their formation is associated with the presence of carbon and metal in the sample, and also depends on the moisture content of the samples for their formation (Fomenko et al., 2011). Thus, the shortage of cenospheres in this study's samples may be related to the drying carried out before the burning process.

Fig. 3 shows micrographs with the results of EDS mapping at different adsorption spectra, it was possible to verify the mineral material that constitutes the ashes.

It was possible to confirm the same structures in all treatments. The following structures were present: particles with regular shapes (Fig. 3a), spherical shapes (Fig. 3b), and angular shapes (Fig. 3c). The components identified were calcium (Fig. 3a) and silica (Fig. $3 \mathrm{~b}$ and c). These components are commonly present in the ashes of eucalyptus bark and indicate presence of foreign material in the bark (Fredo et al., 1999; Borlini et al., 2005; González et al., 2009). It is important to define the structures and components in the ashes, to identify the melting temperature of the material. Depending on the components, the melting temperature of biomass ashes can vary from $650^{\circ} \mathrm{C}$ to $1455^{\circ} \mathrm{C}$ (Reinmöller et al., 2015 and Ma et al., 2016).

\section{Conclusion}

By this study, we were able to verify the feasibility of using eucalyptus bark as biofuel. It was identified a high quantity of ash content (T3 $=13.86 \%)$, indicating presence of foreign material in the bark. The 

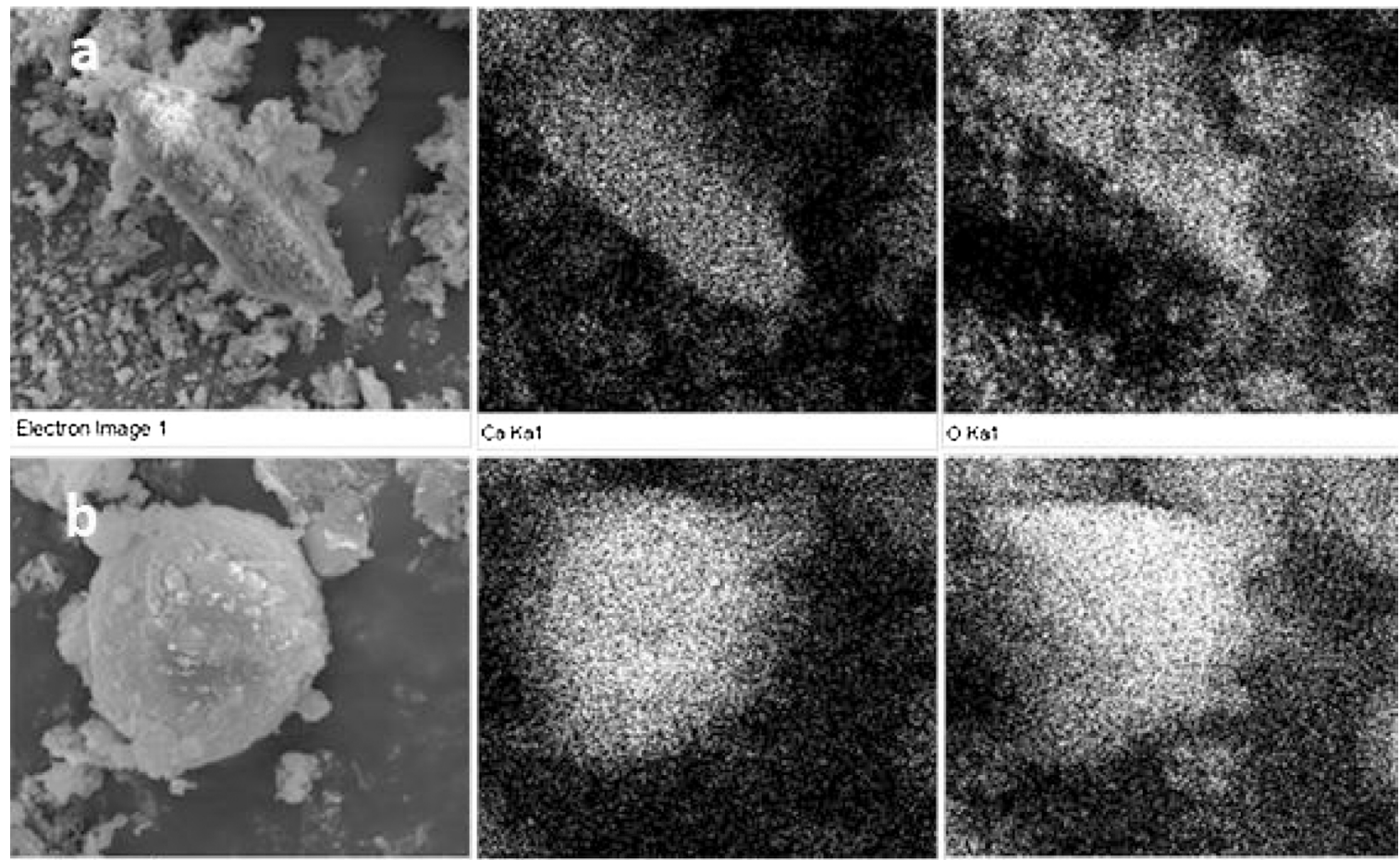

Coral

O Kat
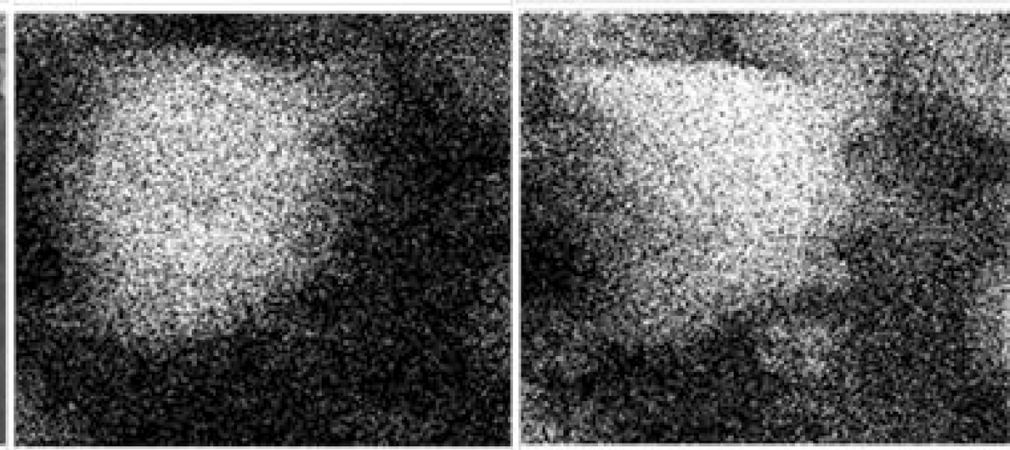

Electron lmage 1

Stal

onat

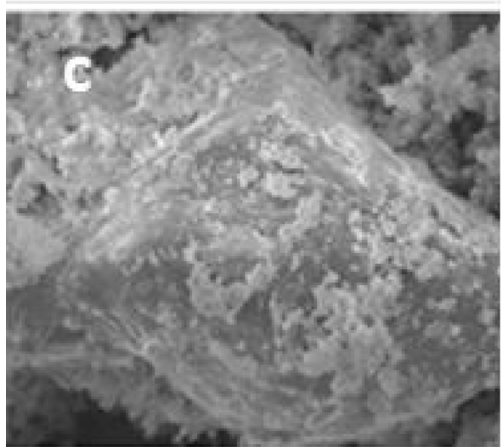

Eectron inage 1

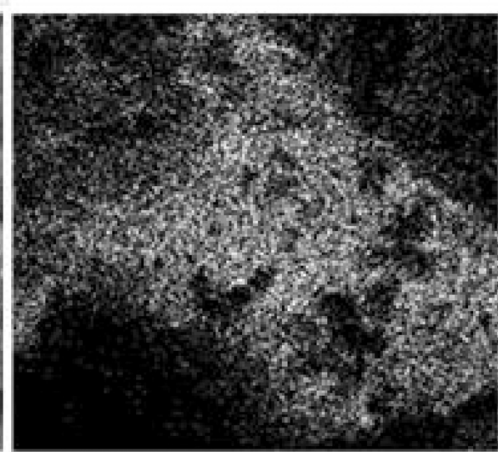

Stist

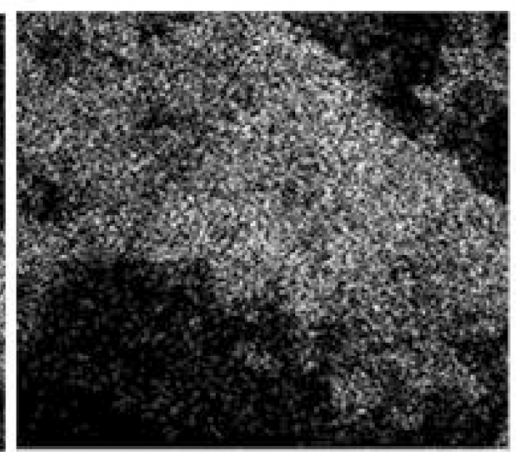

okat

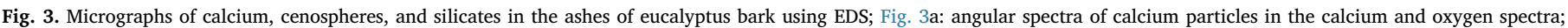
Fig. 3b: Cenospheres in silica and oxygen spectra; Fig. 3c: Silicates in silica and oxygen spectra.

biggest amount of contamination was detected in the smaller particle sizes $(<250 \mu \mathrm{m})$.

The procedures tested here to reduce the mineral contents in the material were washing and separation in different particle sizes. The process of washing did not show efficiency regarding the decrease of impurities in the bark. The process of separation in different particle sizes had a better result and improved the heating efficiency of the biomass analyzed.

\section{Acknowledgements}

The authors thank Prof. Dr. Walter R. Waldman for guidance, as well as the Electron Microscopy Laboratory of the National Nanotechnology Laboratory (LNNano), located at CNPEM (National Center for Research in Energy and Materials), for the use of their facilities, and CNPq for the financial support.

\section{References}

Acquah, G.E., Krigstin, S., Wetzel, S., Cooper, P., Cornier, D., 2016. Heterogeneity of forest harvest residue from eastern Ontario biomass harvests. For. Prod. J. 66, 164-175.

Ahmaruzzaman, M., 2010. A review on the utilization of fly ash. Prog. Energy Combust.
Sci. 36, 327-363.

Akbi, A., Saber, M., Aziza, M., Yassaa, N., 2017. Na overview of sustainable bioenergy potential in Algeria. Renew. Sustain. Energy Rev. 72, 240-245.

Arteaga-Pérez, L.E., Segura, C., Bustamante-García, V., Cápiro, o. G., Jiménez, R., 2015. Torrefaction of wood and bark from Eucalyptus globulus and Eucalyptus nitens: focus on volatile evolution vs feasible temperatures. Energy 93, 1731-1741.

Astm - American Society For Testing And Materials. D 1102-84, Standard Test Method for Ash in Wood. 2 p. 2007.

Astm - American Society For Testing And Materials. D293-93, Standard Test Method for the Sieve Analysis of Coke. 2010.

Astm - American Society For Testing And Materials. D5865-13, Standard Test Method for Gross Calorific Value of Coal and Coke. 2013.

Astm - American Society For Testing And Materials. E872-82, Standard Test Method for Volatile Matter in the Analysis of Particulate Wood Fuels. 2013.

Astm - American Society For Testing And Materials. E871-13, Standard Test Method for Moisture Analysis of Particulate Wood Fuels. 2013.

Blissett, R.S., Rowson, N.A., 2012. A review of the multi-component utilization of coal fly ash. Fuel 97, 1-23.

Borlini, M.C., Sales, H.F., Vieira, C.M.F., Conte, R.A., Pinatti, D.G., Monteiro, S.N., 2005 Cinza da lenha para aplicação em cerâmica vermelha. Parte I: características da cinza. Cerâmica 51, 192-196.

Boumanchar, I., Chhiti, Y., Alaoui, F.E.M., Ouinani, A., Sahibed-Dine, A., Bentiss, F., Jama, C., Bensitel, M., 2017. Effect of materials mixture on the higher heating value: case of biomass, biochar and municipal solid waste. Waste Manage. 61, 78-86.

Brand, M.A., 2010. Energia De Biomassa Florestal, Interciências, 1st ed. Rio de Janeiro. Brito, J.O., Barrichelo, L.E.G., 1978. Características do eucalipto como combustível: análise química imediata da madeira e da casca, Ipef16 63-70.

Chen, M., Yu, D., Wei, Y., 2015. Evaluation on ash fusion behavior of eucalyptus bark/ lignite blends. Powder Technol. 286, 39-47. 
Cordeiro, G.C., Toledo Filho, R.D., Tavares, L.M., Fairbairn, E.R.M., 2008. Pozzolanic activity and filler effect of sugar cane bagasse ash in Portland cement and lime mortars. Cem. Concr. Compos. 30, 410-418.

Cordero, T., Marquez, F., Rodriguez-Mirasol, J., Rodriguez, J.J., 2001. Predicting heating values of lignocellulosics and carbonaceous materials from proximate analysis. Fuel $11,1567-1571$.

Eia, 2015. Energy Information Administration Electricity Supply, Disposition, Prices and Emissions.

Enplus, 2015. Quality Certification Scheme for Wood Pellets, Part 2. Enplus Handbook. $10 \mathrm{p}$.

Erol, M., Haykiri-Acma, H., Kbayrak, S.K., 2010. Calorific value estimation of biomass from their proximate analyses data. Renew. Energy 35, 170-173.

Fomenko, E.V., Anshits, N.N., Panvoka, M.V., Solovyov, L.A., Anshits, A.G., 2011. Fly Ash Cenospheres: Composition, Morphology, Structure, and Helium Permeability. World ofCoalAsh (WOCA) Conference 9-12.

Fredo, A., Foelkel, E.E.B., Frizzo, S.M.B., Silva, M.C.M., 1999. Elementos minerais em madeiras de eucaliptos e acácia negra e sua influência na indústria de celulose Kraft branqueada. Ciência Florestal 9, 193-209.

Furtado, T.S., Ferreira, J.C., Brand, M.A., Neves, M.D., 2012. Correlação entre teor de umidade e eficiência energética de resíduos de Pinus taeda em diferentes idades. Revista Árvore 36, 577-582.

Garcia, R., Pizarro, C., Lavín, A.G., Bueno, J.L., 2014. Spanish biofuelsheatingvalueestimation. Part II: proximateanalysis data. Fuel 117, 1139-1147.

Gominho, J., Lourenço, A., Miranda, I., Pereira, H., 2012. Chemical and fuel properties of stumps biomass from Eucalyptus globulus plantations. Ind. Crops Prod. 39, 12-16.

González, A., Navia, R., Moreno, N., 2009. Fly ashes from coal and petroleum cokecombustion: current and innovative potential applications. Waste Manage. Res. 27, 976-987.

Hansted, A.L.S., Nakashima, G.T., Martins, M.P., Yamamoto, H., Yamaji, F.M., 2016. Comparative analyses of fast growing species in different moisture content for high quality solid fuel production. Fuel 184, 180-184.

Hwang, J.Y., Sun, X., Li, Z., 2002. Unburned carbon from fly ash for mercury adsorption: I. separation and characterization of unburned carbon. J. Miner. Mater. Charact. Eng. $1,39-60$.

Ibá, Indústria Brasileira de Árvores. 100 p. 2015.

Ma, T., Fan, C., Hao, L., Li, S., Song, W., Lin, W., 2016. Fusion characterization of biomass ash. Thermochim. Acta 638, 1-9.

Madanavake, B.N., Gan, S., Eastwick, C., Ng, H.K., 2017. Biomass as an energy source in coal co-firing and its feasibility enhancement via pre-treatment techniques. Fuel Process. Technol. 159, 287-305.
Montes, C.S., Silva, D.A., Garcia, R.A., Muñis, G.I.B., Webera, J.C., 2011. Calorific value of Prosopisafricana and Balanitesaegyptiaca wood: relationships with tree growth, wood density and rainfall gradients in the West African Sahel. Biom. Bioenergy 35, 346-353.

Moraes, F.A.B., 2013. Uso de caldeiras de biomassa e turbo gerador. Revista da Madeira 135.

Nakashima, G.T., Martins, P.M., Hansted, A.L.S., Yamamoto, H., Yamaji, F., 2017. Sugarcane trash for energy purposes: storage time and particle size can improve the quality of biomass for fuel? Ind. Crops Prod. 108, 641-648.

Nematollahi, O., Hoghooghi, H., Rasti, M., Sedaghat, A., 2016. Energy demands and renewable energy resources in the Middle East. Renew. Sustain. Energy Rev. 54, 1172-1181.

Pereira, J.C.D., Sturion, J.A., Higa, A.R., Shimizu, J.Y., 2000. Características Da Madeira De Algumas Espécies De Eucalipto Plantadas No Brasil, Embrapa Florestas, Colombo, 1st. ed.

Protásio, T.P., Bufalino, L., Tonoli, G.H.D., Trugilho, P.F., 2011. Relaáão entre o poder calorçfico superior e os componentes elementares e minerais da biomassa vegetal. Pesquisa Florestal Brasileira 31, 113-122.

Reinmöller, M., Klinger, M., Schreiner, M., Gutte, H., 2015. Relationship between ash fusion temperatures of ashes from hard coal, brown coal, and biomass and mineral phases under different atmospheres: a combined FactSage ${ }^{\mathrm{TM}}$ computional and network theoretical approach. Fuel 151, 118-123.

Sabatti, M., Fabbrini, F., Harfouchea, A., Beritognola, I., Mareschi, L., Carlini, M., Paris, P., Scarascia-Mugnozza, G., 2014. Evaluation of biomass production potential and heating value of hybrid poplar genotypes in a short-rotation culture in Italy. Ind. Crops Prod. 61, 62-73.

Shen, J., Zhu, S., Liu, H., Zhang, J., Tan, J., 2010. The prediction of elemental composition of biomass based on proximate analysis. Energy Convers. Manage. 5, 983-987.

Telmo, C., Lousada, J., 2011. Heating values of wood pellets from different species. Biom. Bioenergy 35, 2634-2639.

Todaro, L., Rita, A., Cetera, P., D́Auria, M., 2015. Thermal treatment modifies the calorific value and ash content in some wood species. Fuel 140, 1-3.

Vanloo, S., Koppejan, J., 2002. Handbook of Biomass Combustion and Co-Firing. Twente University Press, Enschede Netherlands.

Vassilev, S.V., Vassileva, G.C., 2007. A new approach for the classification of coal fly ashes based on their origin, composition, properties, and behavior. Fuel 86 $1490-1512$.

Yu, D., Chen, M., Wei, Y., Niu, S., Xue, F., 2016. An Assessment on co-combustion characteristics of Chinese lignite and eucalyptus bark with TG-MS technique. Powder Technol. 294, 463-471. 